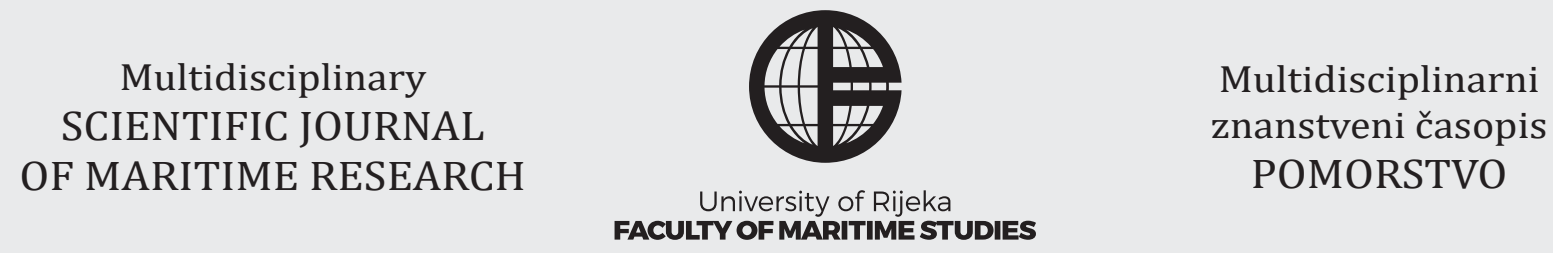

https://doi.org/10.31217/p.35.1.4

\title{
A gas turbine combustion chamber modeling by physical model
}

\author{
Ivica Glavan, Igor Poljak, Mate Kosor \\ University of Zadar, Maritime Department, M. Pavlinovića 1, 23000 Zadar, Croatia, e-mail: iglavan@unizd.hr
}

\section{ABSTRACT}

The validity of the gas turbine unit model largely depends on the accuracy of the flue gas temperature value calculation at the gas turbine inlet (TIT). This temperature is determined by the maximum combustion temperature. In variable running mode, the temperature value is regulated by changing the ratio of air and fuel at the inlet to the combustion chamber. The paper presents a model of a gas turbine combustion chamber using Modelica, an object-oriented language for modeling complex physical systems with the aim of determining the temperature of combustion flue gases, specific heat capacity, enthalpy, and flue gas composition at different gas turbine loads.

\section{ARTICLE INFO}

Preliminary communication

Received 2 March 2021

Accepted 13 April 2021

Key words:

Gas turbine

Combustion chamber

Combustion temperature

Modelica

SimulationX

\section{Introduction}

The combustion chamber is an important link in the modeling of a gas turbine unit. The exhaust gas values from the gas turbine and their magnitude outlet from the combustion chamber affects the accuracy of the calculation of the entire gas turbine model. In cases of modeling a heat turbine due to the complexity of the combustion temperature calculation, it is often assumed that the flue gas temperature at the outlet of the combustion chamber is an isotherm which is not the case in reality and leads to inaccurate values in the calculation. As efficiency of the entire gas turbine process depends largely on the combustion process in the combustion chamber, many researches were conducted in that direction. Railckas et al., [1] carried out CFD simulations to see the operation of a gas turbine combustion chamber with the STARCCM software where they compared simulation results with the operating parameters of the actual process. Comparison results are in the congruence with the actual running gas turbine. The transient combustion models were simulated by Large Eddy Simulations (LES) data, [2]. Combustion model in that study descripts turbulent premixed combustion, which is encountered at the injector exit of gas turbines combustor, by using the Coherent Flame Model (CFM) formalism, where tried to increase the range of validity of this $0 \mathrm{D}$ combustion model to a high number of aero engine combustor geometries, but without satisfactory results in the turbulence and the vortex definition. The turbulence models were modelled successfully by a URANS formulation in [3], using the SST turbulence model, as the basic modelling approach. The numerical results obtained by different turbulence models are comparable with the overall performance and have a fair overall agreement with the experimental data, what is their validation. The combustion chambers are components which produce the highest destruction rate in open cycle gas turbines $[4,5]$. The similar conclusion can be found in [6] for closed cycle gas turbines where the highest destruction rate occurs in main heater (or more of them). All of the combustion (or heat exchange) processes in gas or steam turbines can be improved and optimized by using various machine learning methods [7-10]. The advantage of these approaches is in very low relative error in comparison with the available data. 
For the purpose of calculating the combustion temperature, it is necessary to use thermodynamic data which are described by interpolation curves of specific heat capacity and enthalpy which are known in the literature [11-13] and are often used for modeling purposes. These functions describe the properties of combustion participants with sufficient accuracy. As the range of interpolated values covers the temperature ranges of 300-1000 and 1000$5000 \mathrm{~K}$ these interpolations show large deviations in the calculation of the flue gas temperature in the combustion chamber of the gas turbine, which can be up to $100 \mathrm{~K}$. The reason for this phenomenon lies in the fact that the temperature range of combustion chambers are in the interval of 900-1250 K which just falls between these two intervals. To address this problem they were made on the basis of data [14] new interpolation curves (Table 1 and Table 2) with a higher degree of accuracy and based on them a combustion chamber model was made which in the iterative procedure calculates the combustion temperature flue gas composition, specific heat capacity, average flue gas heat capacity and enthalpy of the exhaust gases.

\section{The combustion participants thermodynamic properties}

Gases that occur in the process of complete combustion are $\mathrm{CO}_{2}, \mathrm{H}_{2} \mathrm{O}(\mathrm{g}), \mathrm{N}_{2}, \mathrm{O}_{2}$ which values are coefficients for calculating the heat capacity and enthalpy of gases given in Tables 1 and 2. The enthalpy of combustion gases (flue gases) is calculated by expression:

$$
h(T)=\int_{T_{0}}^{T} c_{p} d T
$$

where heat capacities in the Table 1 are calculated by:

$$
c_{p}(T)=a_{1}+a_{2} T
$$

where heat enthalpy in the Table 2 are calculated by:

$$
h(T)=a_{1}+a_{2} T+a_{3} T^{2}
$$

Table 1 Combustion gases heat capacity coefficients

\begin{tabular}{|c|c|c|c|c|}
\cline { 2 - 5 } \multicolumn{2}{c|}{} & $\mathbf{2 2 0 - 8 0 0 ~ K}$ & $\mathbf{8 0 0 - 1 5 0 0 ~ K}$ & $\mathbf{1 5 0 0 - 2 5 0 0 ~ K}$ \\
\hline $\mathrm{CO}_{2}$ & $\mathrm{a}_{1}$ & 0,02913557 & $4,45264 \mathrm{E}-02$ & 0,052758903 \\
\hline $\mathrm{H}_{2} \mathrm{O}_{\mathrm{g})}$ & $\mathrm{a}_{2}$ & $2,99640 \mathrm{E}-05$ & $9,70935 \mathrm{E}-06$ & $3,70306 \mathrm{E}-06$ \\
\hline $\mathrm{N}_{2}$ & $\mathrm{a}_{1}$ & $3,03695 \mathrm{E}-02$ & $2,90995 \mathrm{E}-02$ & $3,72788 \mathrm{E}-02$ \\
\hline & $\mathrm{a}_{2}$ & $9,93150 \mathrm{E}-06$ & $1,21192 \mathrm{E}-05$ & $6,83606 \mathrm{E}-06$ \\
\hline $\mathrm{O}_{2}$ & $\mathrm{a}_{1}$ & $2,76147 \mathrm{E}-02$ & $2,77732 \mathrm{E}-02$ & $3,24244 \mathrm{E}-02$ \\
\hline & $\mathrm{a}_{2}$ & $4,23709 \mathrm{E}-06$ & $4,90748 \mathrm{E}-06$ & $1,75613 \mathrm{E}-06$ \\
\hline & $\mathrm{a}_{1}$ & $2,65373 \mathrm{E}-02$ & $3,08985 \mathrm{E}-02$ & $3,30255 \mathrm{E}-02$ \\
\hline
\end{tabular}

Source: Authors

Table 2 Combustion gases enthalpy coefficients

\begin{tabular}{|c|c|c|c|c|}
\cline { 2 - 5 } \multicolumn{2}{c|}{} & $\mathbf{2 2 0 - 8 0 0 ~ K}$ & $\mathbf{8 0 0 - 1 5 0 0 ~ K}$ & $\mathbf{1 5 0 0 - 2 5 0 0 ~ K}$ \\
\hline \multirow{3}{*}{$\mathrm{CO}_{2}$} & $\mathrm{a}_{1}$ & $-6,35634 \mathrm{E}-01$ & $-6,35634 \mathrm{E}-01$ & $-1,21288 \mathrm{E}+01$ \\
\cline { 2 - 5 } & $\mathrm{a}_{2}$ & $2,91356 \mathrm{E}-02$ & $4,45264 \mathrm{E}-02$ & $5,27589 \mathrm{E}-02$ \\
\cline { 2 - 5 } & $\mathrm{a}_{3}$ & $1,49820 \mathrm{E}-05$ & $4,85467 \mathrm{E}-06$ & $1,85153 \mathrm{E}-06$ \\
\cline { 2 - 5 } & $\mathrm{a}_{1}$ & $4,02478 \mathrm{E}-01$ & $7,31029 \mathrm{E}-01$ & $-5,64619 \mathrm{E}+00$ \\
\cline { 2 - 5 } $\mathrm{H}_{2} 0_{(\mathrm{g})}$ & $\mathrm{a}_{2}$ & $3,03695 \mathrm{E}-02$ & $2,90995 \mathrm{E}-02$ & $3,72788 \mathrm{E}-02$ \\
\hline \multirow{3}{*}{$\mathrm{N}_{2}$} & $\mathrm{a}_{3}$ & $4,96575 \mathrm{E}-06$ & $6,05960 \mathrm{E}-06$ & $-3,55367 \mathrm{E}+00$ \\
\cline { 2 - 5 } & $\mathrm{a}_{1}$ & $2,42385 \mathrm{E}-01$ & $2,9,06821 \mathrm{E}-02$ & $3,24244 \mathrm{E}-02$ \\
\cline { 2 - 5 } & $\mathrm{a}_{2}$ & $2,76147 \mathrm{E}-02$ & $2,45374 \mathrm{E}-06$ & $8,78063 \mathrm{E}-07$ \\
\hline \multirow{3}{*}{$\mathrm{O}_{2}$} & $\mathrm{a}_{3}$ & $2,11854 \mathrm{E}-06$ & $-1,47096 \mathrm{E}+00$ & $-2,92248 \mathrm{E}+00$ \\
\cline { 2 - 5 } & $\mathrm{a}_{1}$ & $3,57855 \mathrm{E}-01$ & $3,08985 \mathrm{E}-02$ & $3,30255 \mathrm{E}-02$ \\
\cline { 2 - 5 } & $\mathrm{a}_{2}$ & $2,65373 \mathrm{E}-02$ & $1,96869 \mathrm{E}-06$ & $1,18712 \mathrm{E}-06$ \\
\hline
\end{tabular}




\section{The control volume of the combustion chamber}

As the adiabatic combustion temperature can be over $2200 \mathrm{~K}$ [15] on the example of Methane, $\mathrm{CH}_{4} \Phi=1$ is $T_{\text {adiabatic }}=2267.2 \mathrm{~K}[16]$. Such high amounts of temperature at the outlet of the combustion chamber would cause damage to the gas turbine blades especially on gas models turbines of lower power (up to $5 \mathrm{MW}$ ) which do not have blade cooling implemented. The solution to this the problem can be obtained by bringing 3 to 6 time larger amount of air than required by stoichiometric calculation [17], in order to maintain the inlet temperature of the gas turbine (TIT) as high enough as to allow optimally turbine power at which the turbine blades will not be destroyed.

Adiabatic combustion temperature $T_{\text {adiabatic }}$ the maximum flue gas temperature inside combustion chambers [18].

\subsection{Adiabatic temperature calculation, $T_{\text {adiabatic }}$}

By applying the first law of thermodynamics to the control volume of the combustion chamber it may be written [19]:

$$
\begin{aligned}
& Q-W=H_{P}-H_{R}= \\
& =\sum_{P} N_{i}\left(h_{f}^{o}+h-h^{o}\right)_{i}-\sum_{R} N_{i}\left(h_{f}^{o}+h-h^{o}\right)_{i}
\end{aligned}
$$

where enthalpy of product and reactants of combustion is:

$$
h(T)=h_{f}^{\circ}\left(T^{\circ}\right)+h(T)-h^{\circ}\left(T^{\circ}\right)
$$

The enthalpy of formation $h_{f}^{\circ}$ for the standard reference state (SRS) is taken at $25^{\circ} \mathrm{C}$ and $0,1013 \mathrm{MPa}$. General equation of hydrocarbon combustion is:

$$
\underbrace{C_{x} H_{y}+\left(x+\frac{y}{4}\right) \mathrm{O}_{2}}_{\text {fuel + oxygen }} \rightarrow \underbrace{\mathrm{xCO}_{2}+\left(\frac{y}{2}\right) \mathrm{H}_{2} \mathrm{O}}_{\text {flue gas }}
$$

The first part of equation 6 is reaction of fuel and oxygen and the other part are exhaust gases. General equation of hydrocarbon combustion from the air:

$$
\underbrace{C_{x} H_{y}+a O_{2}+3.7 a N_{2}}_{\text {fuel + air }} \rightarrow \underbrace{x C O_{2}+\left(\frac{y}{2}\right) \mathrm{H}_{2} \mathrm{O}+03.76 a N_{2}}_{\text {flue gas }}
$$

The stoichiometric ratio of air and fuel can be written as:

$$
(A / F)_{s}=\left(\frac{m_{a}}{m_{f}}\right)_{s}
$$

The relative ratio is the ratio of the mixture of air and fuel and the stoichiometric mixture of air and fuel:

$$
\lambda=\frac{(A / F)}{(A / F)_{s}}
$$

A commonly used quantity in practice is the equivalent ratio:

$$
\Phi=\frac{1}{\lambda}=\frac{(A / F)_{s}}{(A / F)}=\frac{(F / A)}{(F / A)_{s}}
$$

Based on the volume amounts from the air mixture whereby there is $21 \% \mathrm{O}_{2}$ and $79 \% \mathrm{~N}_{2}$ in the air it can be written [20], that the stoichiometric mixture of air and fuel then amounts:

$$
(A / F)_{s}=\left(\frac{m_{a}}{m_{f}}\right)_{s}=\frac{4.76\left(x+\frac{y}{4}\right)}{1} \cdot \frac{M_{a}}{M_{f}}
$$

where $M_{\mathrm{a}}$ is molecular air mass and $M_{f}$ is molecular fuel mass.

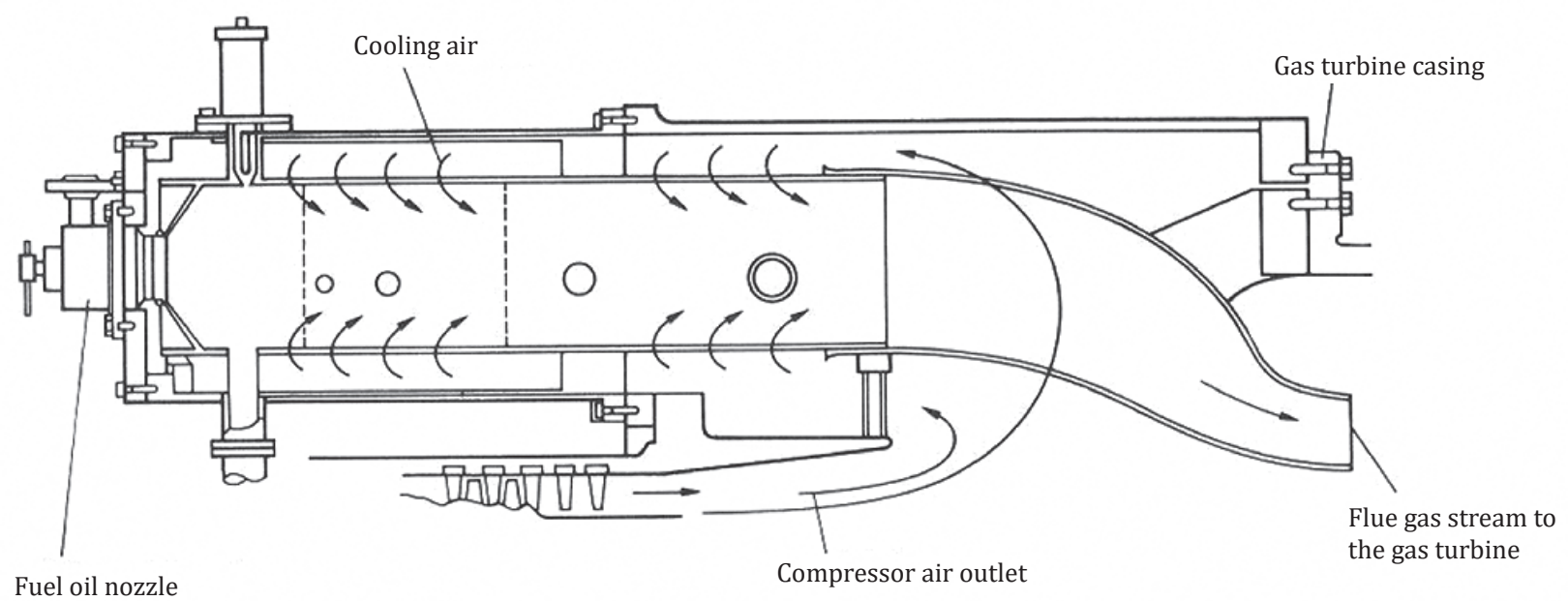

Figure 1 Gas turbine combustion chamber [17] 


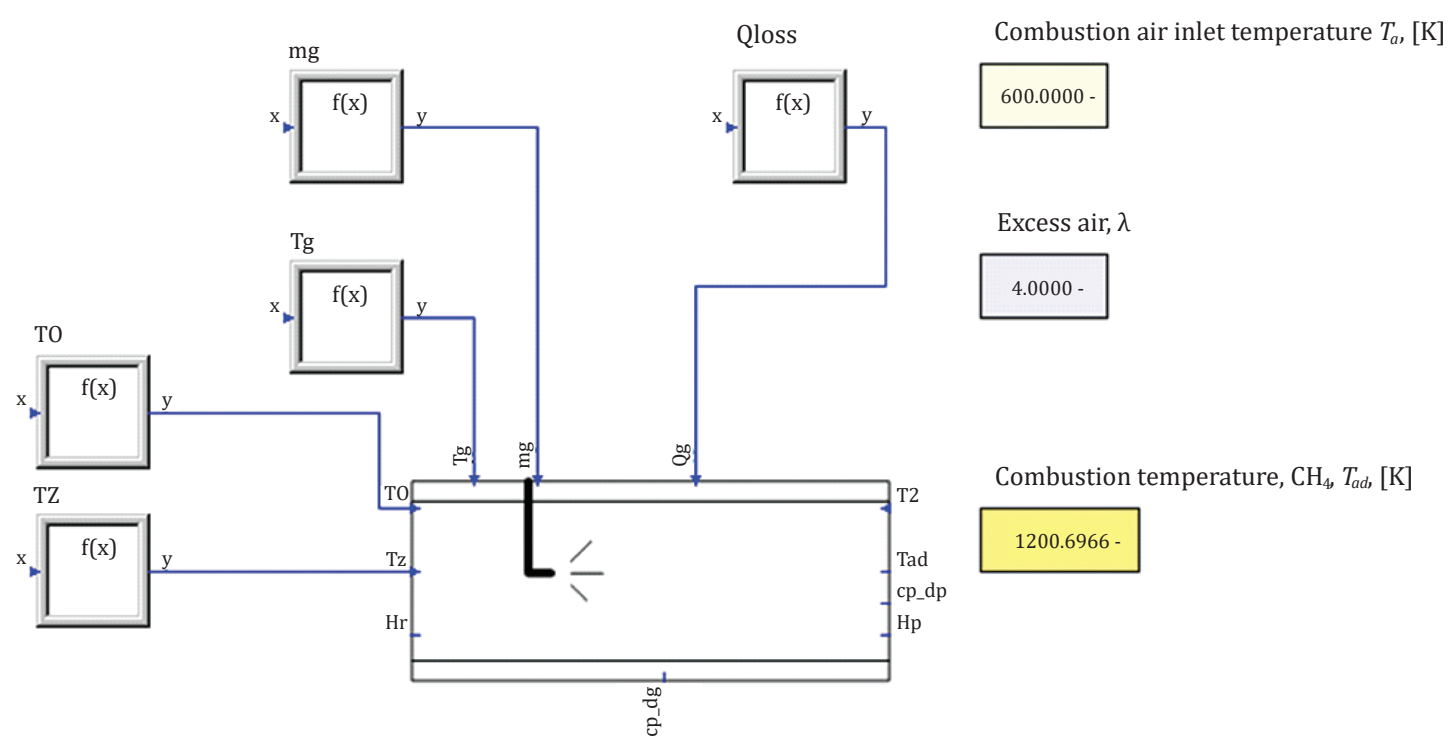

Figure 2 Modelica the combustion chamber model

Source: Authors

\subsection{Nonlinear algebraic combustion equation}

The adiabatic combustion process is described by the nonlinear algebraic equation $f(T)=0$. The procedure for solving this equation is based on the "Regula falsi" method or the secant method [21]. In the procedure it is necessary to perform an iteration in which the temperature $T$ which will be found corresponds to the adiabatic combustion temperature a which represents the zero point of the function. Iteration procedure is based on the iterative scheme described by the equation:

$$
T_{i+1}=\frac{T_{i-1} f\left(T_{i}\right)-T_{i} f\left(T_{i-1}\right)}{f\left(T_{i}\right)-f\left(T_{i-1}\right)}
$$

in which the index $i$ represents an iterative step. The iteration procedure is repeated until it is not satisfied convergence criterion, taking the values of the unknowns calculated from of the previous step

$$
\left|\frac{T_{i+1}-T_{i}}{T_{i}}\right| \leq \varepsilon
$$

\section{Modelling and simulation}

The paper presents a model of a gas turbine combustion chamber using Modelica language, for modeling complex physical systems with the aim of determining the temperature of combustion flue gases, specific heat capacity, enthalpy, and flue gas composition at different gas turbine loads.

Modelica [22] is an open standard for describing physical models and their components, whose is a core object-oriented language, which is suitable for describing complex physical systems from areas such as mechanics, electrical engineering, hydraulics and thermodynamics. The special interest is in the area of the separate production of heat energy from a boiler and cooling energy from a compression refrigeration unit. These are powered with electrical energy from an external network which could be replaced with a CCHP system (combined cooling, heating and power - combined cooling, heating and electricity generation) based on the operation of a gas turbine and absorption refrigeration unit [23, 24]. The mentioned models are given to be described by differential-algebraic equations (DAE). Models described by differential algebraic equations are solved by applying different numerical methods (Euler, Runge - Kutta Dassl). Basing language development and ownership on open source principles has encouraged many manufacturers to develop and implement different versions of Modelica Simulation Environments as OpenModelica [25], MapleSim [26], Wolfram SystemModeler [27], SimulationX [28].

\section{Analysis results and validation}

The Modelica, results of simulations of the combustion chamber model (Table 3 and Figure 3) of $\mathrm{CH}_{4}$, for variated values relative ratio $\lambda$ and inlet air temperature to the combustion chamber of $600 \mathrm{~K}$ compared to the CHEMCAD [29] and Cantera [30] tool. The CHEMCAD is an integrated suite of intuitive chemical process simulation software that fits into the chemical engineering workflow and supercharges an engineer's efficiency. CHEMCAD combustion chamber tool uses mode of "Gibbs free energy reactor". The CERFACS, [31] is Cantera based Adiabatic Flame Temperature Calculator based on the object-oriented software toolkit for chemical kinetics, thermodynamics, 
Table 3 Comparative results of adiabatic combustion temperature simulation

\begin{tabular}{|c|c|c|c|c|c|}
\hline \multirow[b]{2}{*}{$\lambda$} & \multirow[b]{2}{*}{$\Phi$} & \multirow[b]{2}{*}{$\mathrm{T}_{\mathrm{a}}(\mathrm{K})$} & \multicolumn{3}{|c|}{$\mathrm{T}_{\mathrm{ad}}(\mathrm{K})$} \\
\hline & & & MODELICA & CHEMCAD & CERFACS \\
\hline 3 & 0,3333 & 600 & $1.375,87$ & $1.379,99$ & 1391,98 \\
\hline 4 & 0,2500 & 600 & $1.200,70$ & $1.203,79$ & 1213,82 \\
\hline 4,5 & 0,2222 & 600 & $1.139,85$ & $1.130,15$ & 1151,84 \\
\hline
\end{tabular}

Source: Authors

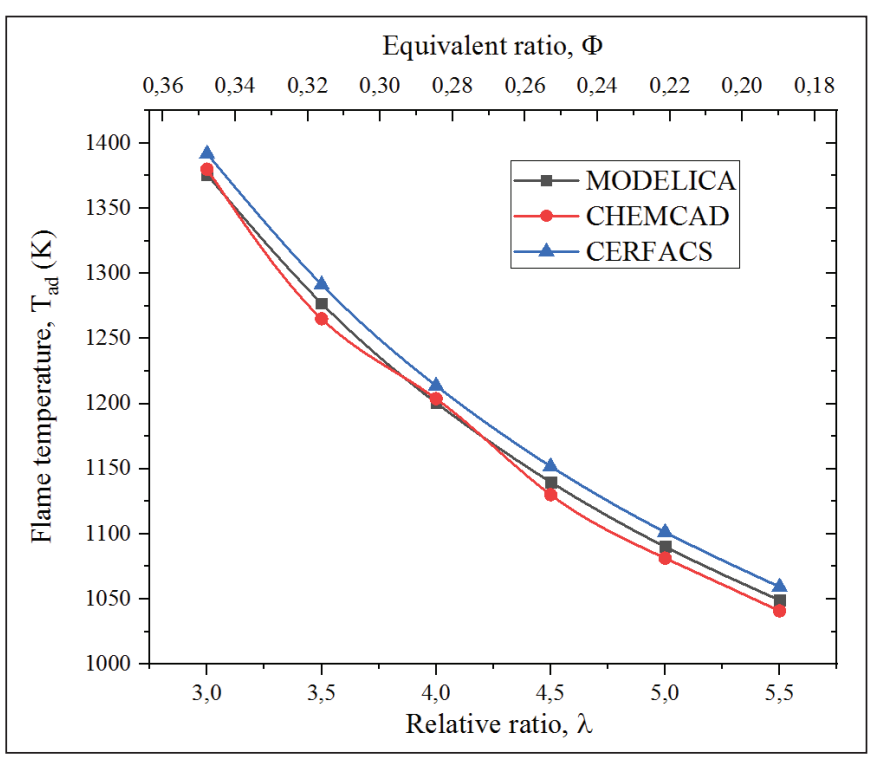

Figure 3 Values of adiabatic flame temperature as a function relative ratio $\lambda$

Source: Authors

and transport processes. The code utilizes object-oriented concepts for robust yet flexible phase models, and algorithms are generalized so that users can explore different phase models with minimal changes to their overall code. Currently, Cantera can be used from Python and MATLAB, or in applications written in $\mathrm{C} / \mathrm{C}++$ and Fortran 90. Cantera also provides a limited number of solvers for time-dependent reactor networks and steady one-dimensional reacting flows.

\section{Conclusion}

The validity of the gas turbine unit model largely depends on the accuracy of the flue gas temperature value calculation at the gas turbine inlet (TIT). This temperature is determined by the temperature of the flame in the combustion chamber. In variable running mode, the temperature value is regulated by changing the air to fuel ratio at the inlet to the combustion chamber. Application of Modelica in the development of a model of the control volume of the combustion chamber of a gas turbine, shows excellent results which allow to make a valid model of a gas turbine unit. Modelica main task is to calculate the combustion temperature of flue gases and the size and volume fraction of individual combustion participants and simulation of combustion chamber operation validated with equipment manufacturer values tools. As the real data for such simulated processes is difficult to collect due to limited research budget the validation of the Modelica (SimulationX) computed values were compared and validated by combustion process simulation with CHEMCAD and CERFACS (Cantera).

\section{Nomenclature}

\section{Abbreviation}

SRS Standard reference state

TIT Temperature of exhaust gases at gas

$[\mathrm{K}]$ turbine inlet

\section{Latin symbols}

$\begin{array}{lll}\text { A } & \text { Air } & \\ \text { F } & \text { Fuel } & \\ \text { h } & \text { Enthalpy } & {[\mathrm{kJ} / \mathrm{kmol}]} \\ \text { m } & \text { Mass flow rate } & {[\mathrm{kg} / \mathrm{s}]} \\ \mathrm{M} & \text { Molar mass } & {[\mathrm{kg} / \mathrm{kmol}]} \\ \mathrm{N} & \text { Plural substance } & \\ \mathrm{r} & \text { Volume ratio } & {[\%]} \\ \mathrm{Q} & \text { Power } & {[\mathrm{kW}]} \\ \mathrm{T} & \text { Temperature } & {[\mathrm{K}]}\end{array}$

\section{Greek symbols}

$\Phi \quad$ Equivalent ratio

$\lambda$ Relative ratio

Index

a Air

ad Adiabatic

f Fuel

fo Formation

g Gas

o Reference

P Product

R Reactant

S stoichiometric 
Funding: The research presented in the manuscript did not receive any external funding.

Author Contributions: Data collection, Ivica Glavan; Methodology, Ivica Glavan and Igor Poljak; Formal analysis, Ivica Glavan; Writing, Ivica Glavan and Igor Poljak; Verification / Mathematical harmonization, Mate Kosor.

\section{References}

[1] P. I. Ralickas, T. B. Marchese, F. Y. Nara, E. M. Yamao, J. Borba F. Chiesa; Combustion Simulation in a Gas Turbine Combustion Chamber, $24^{\text {th }} \mathrm{ABCM}$ International Congress of Mechanical Engineering, December 3-8, 2017, Curitiba, PR, Brazil, DOI: 10.26678/ABCM.COBEM2017.COB17-1306.

[2] E. Rehayem, A. de Kerautem, A. Dulbecco, O. Colin, F. Le Berr; Towards a Novel 0D Gas Turbine Combustor Modeling: Bridging the Gap Between Dimensional and Engine Performance Approaches, $7^{\mathrm{TH}}$ EUROPEAN CONFERENCE FOR AERONAUTICS AND AEROSPACE SCIENCES (EUCASS), DOI: 10.13009/EUCASS2017-249.

[3] A. C. Benim, S. Iqbal, F. Joos, A.r Wiedermann; Numerical Analysis of Turbulent Combustion in a Model Swirl Gas Turbine Combustor, Hindawi Publishing Corporation Journal of Combustion Volume 2016, Article ID 2572035, 12 pages, http://dx.doi.org/10.1155/2016/2572035.

[4] Ibrahim, Thamir K., Firdaus Basrawi, Omar I. Awad, Ahmed N. Abdullah, G. Najafi, Rizlman Mamat, and F. Y. Hagos. "Thermal performance of gas turbine power plant based on exergy analysis." Applied thermal engineering 115 (2017): 977-985. https://doi.org/10.1016/j.applthermaleng.2017.01.032.

[5] Fallah, M., H. Siyahi, R. Akbarpour Ghiasi, S. M. S. Mahmoudi, M. Yari, and M. A. Rosen. "Comparison of different gas turbine cycles and advanced exergy analysis of the most effective." Energy 116 (2016): 701-715. https://doi.org/10.1016/ j.energy.2016.10.009.

[6] V. Mrzljak, I. Poljak, J. Prpić-Oršić, M. Jelić; Exergy analysis of marine waste heat recovery $\mathrm{CO} 2$ closed-cycle gas turbine system, Scientific Journal of Maritime Research 34 (2020), https://doi.org/10.31217/p.34.2.12.

[7] S. B. Šegota, I. Lorencin, N. Anđelić, V. Mrzljak, Z. Car; Improvement of Marine Steam Turbine Conventional Exergy Analysis by Neural Network Application, J. Mar. Sci. Eng. 2020, 8, 884; doi:10.3390/jmse8110884.

[8] I. Lorencin, N. Anđelić, V. Mrzljak, Z. Car; Multilayer Perceptron approach to Condition-Based Maintenance of Marine CODLAG Propulsion System Components, Scientific Journal of Maritime Research 33 (2019) 181-190, https://doi.org/ 10.31217/p.33.2.18.

[9] I. Lorencin, N. Andelić, V. Mrzljak, Z. Car; Genetic Algorithm Approach to Design of Multi-Layer Perceptron for Combined Cycle Power Plant Electrical Power Output Estimation, Energies 2019, 12, 4352; doi:10.3390/en12224352.

[10] Poljak, Igor, Toni Bielić, Vedran Mrzljak, and Josip Orović. "Analysis and Optimization of Atmospheric Drain Tank of
Lng Carrier Steam Power Plant." Journal of Marine Science and Engineering 8, no. 8 (2020): 568. https://doi.org/ 10.3390/jmse8080568.

[11] Heywood J.B., Internal Combustion Engine, McGraw-Hill, 1998, p. 130.

[12] Stephen R. Turns David R. Kraige, PROPERTY TABLES FOR THERMAL FLUIDS ENGINEERING, CAMBRIDGE UNIVERSITY PRESS, 2007, p. 72-74.

[13] Sonntag, Richard E - Borgnakke, Claus - Wylen, Gordon J Van, Fundamentals of Thermodynamics, 2004, Jhon Wiley and Sons, Inc.

[14] Michael J. Moran Howard N. Shapiro, Daisie D. Boettner, Margaret B. Bailey, Fundamentals of Engineering Thermodynamics $7^{\text {th }}$ Edition, Wiley, 2010. Table A-23.

[15] Kawasaki Gas Turbine, www.kawasakigasturbines.com

[16] Stephen R. Turns, An Introduction to Combustion: Concepts and Applications, McGraw-Hill, 2000, Ch2, Heywood J.B., Internal Combustion Engine, McGraw-Hill, 1998, Ch 3].

[17] Hrvoje Požar, Osnove energetike 2, Školska knjiga, 1992 p. 1066.

[18] Kostyuk, A., and V. Frolov, eds. Steam and gas turbines. Mir Pub., 1988.

[19] Mrzljak, Vedran, Igor Poljak, and Vedran Medica-Viola. "Dual fuel consumption and efficiency of marine steam generators for the propulsion of LNG carrier." Applied Thermal Engineering 119 (2017): 331-346. https://doi.org/10.1016/j. applthermaleng.2017.03.078.

[20] Thierry Poinsot, Denis Veynantem, Theoretical and Numerical Combustion Second Edition, Edwards, 2005.

[21] Fawzy El-Mahallawy, Saad El-Din Habik, FUNDAMENTALS AND TECHNOLOGY OF COMBUSTION FUNDAMENTALS, Elsavier, 2002.

[22] Modelica, www.modelica.com

[23] I. Glavan, Z. Prelec, B. Pavković; The techno-economic justification for the changing of a system for separate heating/ cooling and electrical energy production with a CCHP system with a micro-turbine and absorption refrigeration unit, Technical Gazette 23, 1(2016), 99-106, DOI: 10.17559/TV20150702122617.

[24] I. Glavan, Z. Prelec, B. Franković; Dinamička simulacija trigeneracijskog sustava male snage s plinskim motorom i apsorpcijskim rashladnim uređajem, // 30 $0^{\text {th }}$ International Scientific \& Expert Meeting of Gas Professionals / Šunić, Miljenko (ur.). Zagreb, 2015. str. 38-38.

[25] Open Modelica, www.openmodelica.org

[26] MapleSim , www.maplesoft.com/products/maplesim/

[27] Wolfram SystemModeler, www.wolfram.com/system-modeler

[28] ESI SimulationX, www.simulationx.com

[29] CHEMCAD, www.chemstations.com

[30] Cantera, www.cantera.org

[31] CERFACS (Centre Européen de Recherche et de Formation Avancée en Calcul Scientifique), www.cerfacs.fr 